\title{
The results of the "Blue Cards" questionnaire analysis with respect to the incidence of violence among the elderly
}

\author{
MARTA GIEZEK ${ }^{1, A-E}$, MARTA BAŻYD $\mathrm{O}^{2,}$, в, JACEK CIECHOWICZ ${ }^{1, \text { в }}$, BARBARA MASNA ${ }^{3, \text { в }}$, \\ PAULINA ZABIELSKA ${ }^{2, ~ B}$, JOANNA TOMCZAK ${ }^{1, F}$, MONIKA PASZKIEWICZ ${ }^{2,8}$, \\ KRZYSZTOF SAFRANOW ${ }^{4, C}$, BEATA KARAKIEWICZ ${ }^{2, ~ G}$
}

${ }^{1}$ Municipal Family Help Centre in Szczecin

${ }^{2}$ Department and Unit of Public Health, Pomeranian Medical University in Szczecin

${ }^{3}$ Community Mutual Aid Center in Szczecin

${ }^{4}$ Department of Biochemistry and Medical Chemistry, Pomeranian Medical University in Szczecin

A - Study Design, B - Data Collection, C - Statistical Analysis, D - Data Interpretation, E - Manuscript Preparation, F - Literature Search, $\mathbf{G}$ - Funds Collection

Summary Background. Implementation of the "Blue Cards" procedure has resulted in an increase in reported acts of violence, including those concerning the elderly, not because violence has become more widespread, but because the principles of the fight against domestic violence have been established and competencies of the relevant services have been distributed.

Objectives. The aim of the study is to review the "Blue Cards" questionnaires of people over the age of 60 involved in domestic violence. Material and methods. The study involved 1,299 "Blue Cards" questionnaires, which were obtained in the years 2012-2013 by the Interdisciplinary Team dealing with domestic violence prevention in Szczecin. From this sample, 312 forms obtained from individuals above the age of 60 were analyzed.

Results. Elderly people are involved in violence in three ways: as individuals experiencing violence, as those who use violence or as individuals who witnesses violence. Without a doubt, the majority of people who are affected by violence are women who are harmed by their husbands. Domestic violence amongst elderly people is usually disclosed after 1-3 years of its duration; however, it occasionally happens after more than 7 years. The dominant emotion in victims of domestic violence is fear, and in perpetrators - aggression. Conclusions. There are still many cases of domestic violence amongst people over 60 years of age that remain undisclosed, hence co-operation amongst services is extremely important, as well as continuously raising the competence of police officers, education, social assistance and health care specialists. The aim is to counteract violence amongst the elderly and to restore balance to their daily functioning.

Key words: the elderly, domestic violence, public policy.

Giezek M, Bażydło M, Ciechowicz J, Masna B, Zabielska P, Tomczak J, Paszkiewicz M, Safranow K, Karakiewicz B. The results of the "Blue Cards" questionnaire analysis with respect to the incidence of violence among the elderly. Fam Med Prim Care Rev 2017; 19(1): 18-22, doi: 10.5114/fmpcr.2017.65085.

\section{Background}

World Health Organization defines elder abuse as intentional or unintentional acts of abuse or neglect [1]. The definition confirms the research by M. Halicka, which points to abuse and neglect as the most common forms of violence against the elderly [2]. According to the WHO report (June 2011), every year at least 4 million elderly people in Europe become victims of physical violence, 29 million - psychological violence, 6 million are victims of fraud and theft, and approx. 2.5 thousand seniors are killed by family members [3]. Research conducted by Abuse and Violence against Older Women in Europe (AVOW-study) in Finland, Austria, Belgium, Portugal and Lithuania in 2010, on a total sample of 2,880 older women (not living in institutions), indicates that $28.1 \%$ of women were exposed to violence, including physical violence $2.5 \%$, sexual violence $-3.1 \%$, neglect $-5.4 \%$, violation of civil rights $-6.4 \%$, economic violence $-8.8 \%$ and psychological violence $-23.6 \%$ [4]. Swiss research shows that out of the studied 150 cases of violence against the elderly, 30\% - involved neglect, $47 \%$ - psychological violence, $35 \%$ - economic violence and $30 \%$ - physical violence [5]. Elder abuse is carried out mainly by family members, adult children, grandchildren or spouses [6]. Acts of violence among individuals over the age of 60 are rarely single incidents; the violence lasts for years and increases with time until it is finally disclosed. Reports of violence are usually made by witnesses or by victims themselves. According to data published by the National Center on Elder Abuse in the United States, reported violence accounts for $16 \%$ of all cases, and the remaining $84 \%$ are unreported or unidentified cases of violence [7]. Despite an increase in public awareness, a growing number of publications on the topic of violence among older people (558 publications in 1959-1990, and as many as 1,368 publications in 1991-2006) [8] and an increase in the number of disclosures of violence in families in which older people function, a realistic assessment of the phenomenon is still impossible. The research commissioned by the Ministry of Labor and Social Policy in 2014 shows that $75 \%$ of individuals experiencing domestic violence do not seek help from any institution [9]. Elderly victims of violence remain with the perpetrators largely due to their dependence on the perpetrators, but also due to the shame of public opinion, cultural and religious beliefs, as well as emotional ties [10]. Non-disclosure of violence is also associated with the victims' belief about the lack of services' effectiveness when dealing with the perpetrators, as well as the fear of the elderly, mostly women, of retaliation by the perpetrator [6]. National police statistics for 2014 show that approx. $70 \%$ of victims of domestic violence are women, approximately 
$10 \%$ are men, and the remaining $20 \%$ are minors. At the same time, approx. $93 \%$ of all perpetrators are men [11].

The amendment of the Act of 29 July 2005 on the prevention of domestic violence, made in 2010 [4], imposed on the Council of Ministers the requirement for issuing a regulation on the "Blue Cards" procedure and forms which, following extensive consultations, were adopted on 13 September 2011 [12]. The "Blue Cards" procedure establishes the following important principles:

- the procedure is initiated in the case of reasonable suspicion of the existence of violence, even if it is not supported by any evidence. Further procedures aim to establish whether the suspicion was justified or not;

- the consent of the individual affected by domestic violence is not required;

- it is carried out with the cooperation of the police, social welfare, education and health services and the committee on alcohol problems, i.e. entities authorized and obliged to act within the procedure;

- it orders to immediately notify the police or the prosecutor's office of suspicion of domestic violence, which is a criminal offense prosecuted ex officio [13].

The inclusion, after more than six years, of the above-mentioned regulation into Polish law resulted in an increase in the number of reported acts of violence, including those involving the elderly, not because violence has become more widespread, but because specific rules concerning its occurrence or even just a reasonable suspicion of its occurrence have been established.

\section{Objectives}

The aim of the study was to assess the phenomenon of violence among the elderly on the basis of the "Blue Cards" questionnaires.

\section{Material and methods}

The study involved 1,299 "Blue Cards" questionnaires submitted in the years 2012-2013 to the Interdisciplinary Team for Prevention of Domestic Violence in Szczecin - 577 cards in 2012 and 722 cards in 2013. We analyzed 312 forms completed for individuals over 60 years of age, including 108 forms in 2012 and forms in 2013. The pattern of "Blue Cards" forms results from the Government Order of 13 September 2011 on the "Blue Cards" procedure and the model of "Blue Cards" forms. The study focused on the analysis of the " $A$ " form of the "Blue Cards" questionnaire, which initiates the procedure. This form is a seven-page document containing information on the organization initiating the procedure, individuals experiencing violence, individuals reporting violence and those suspected of the use of violence, including their names, addresses and degree of kinship. It also defines the forms of violence, its duration, behavior of the victim and the offender during the intervention, description of the scene of the crime, individuals sharing the place of residence and witnesses, including their names and addresses. The " $\mathrm{A}$ " form does not require information concerning the age of individuals experiencing violence or those suspected of its use. This information was most frequently added by the services initiating the procedure or, failing that, necessitated an analysis of other documents collected during the procedure (community interviews conducted by social workers). The research method was a diagnostic survey based on an analysis of the documents. It was assumed that any type of violence is detrimental to the victim and results in their pain, suffering and loss. The analysis of the types and forms of violence was omitted due to a number of studies indicating a quantitative image of older people involved in psychological, physical, sexual and economic violence, as well as through neglect. The research material was used to assess the scale of the phenomenon and its duration. The research process does not require the consent of the Bioethics Committee (information dated 18 June 2014, KB0012/47/06/2014). All authors have obtained consent to the processing of the relevant personal data.

\section{Results}

The study shows that 312 "Blue Cards", which accounts for $24.02 \%$ of 1,299 cases initiated in 2012-2013, refer to people above 60 years of age. Older people are involved in violence in three dimensions: as victims of violence, as perpetrators of violence and as witnesses of violence. This allows for an overall assessment of the phenomenon of violence in a way that goes beyond the standard focus on seniors experiencing harm (Table 1 ).

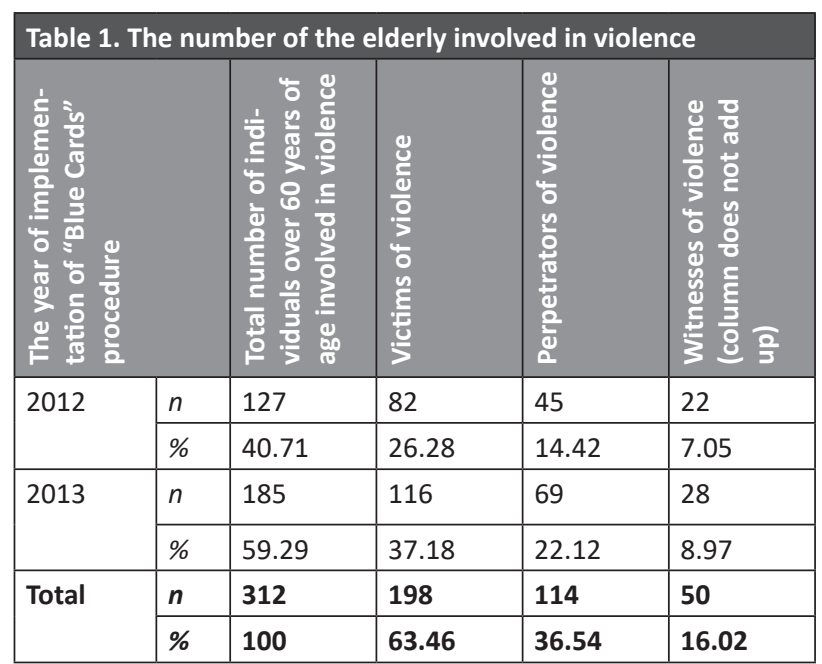

Source: Authors' own research.

An important factor in the phenomenon of violence is the gender of the victim. In this respect, violence among individuals over 60 years of age does not differ from statistics on individuals in other age groups. In Poland, we have observed that the majority of victims are women, who in total represent $51.6 \%$ of the population, but in the age group of 70-74 years, women represent almost $60 \%$; this advantage increases with the aging of the population $[11,14]$ (Table 2 ).

Table 2. The gender of respondents involved in violence

\begin{tabular}{|l|l|l|l|}
\hline \multicolumn{2}{|l|}{ Gender } & Victims of violence & Perpetrators of violence \\
\hline \multirow{3}{*}{ Women } & $n$ & 153 & 8 \\
\cline { 2 - 4 } & $\%$ & 77.20 & 7.02 \\
\hline \multirow{2}{*}{ Men } & $n$ & 45 & 106 \\
\cline { 2 - 4 } & $\%$ & 22.72 & 92.98 \\
\hline
\end{tabular}

Source: Authors' own research.

An important aspect of the analysis of violence towards the elderly is the degree of relationship of the perpetrators with their victims. The results shown in Figure 1 demonstrate that, among individuals over 60 years of age, violence is most often caused by spouses or cohabitees. Alarmingly, 103 individuals, which accounts for $15.79 \%$ of the perpetrators, used violence against ascendants over 80 years of age. More than half of the respondents had experienced violence from their children and grandchildren (Figure 1).

Another characteristic factor of violence among seniors is its lengthy duration. The reasons for the silent suffering of elderly people experiencing violence within the family depend on two most common situations in which there is violence and neglect of the needs of the elderly $[8,15]$. Firstly, when, due to an illness 


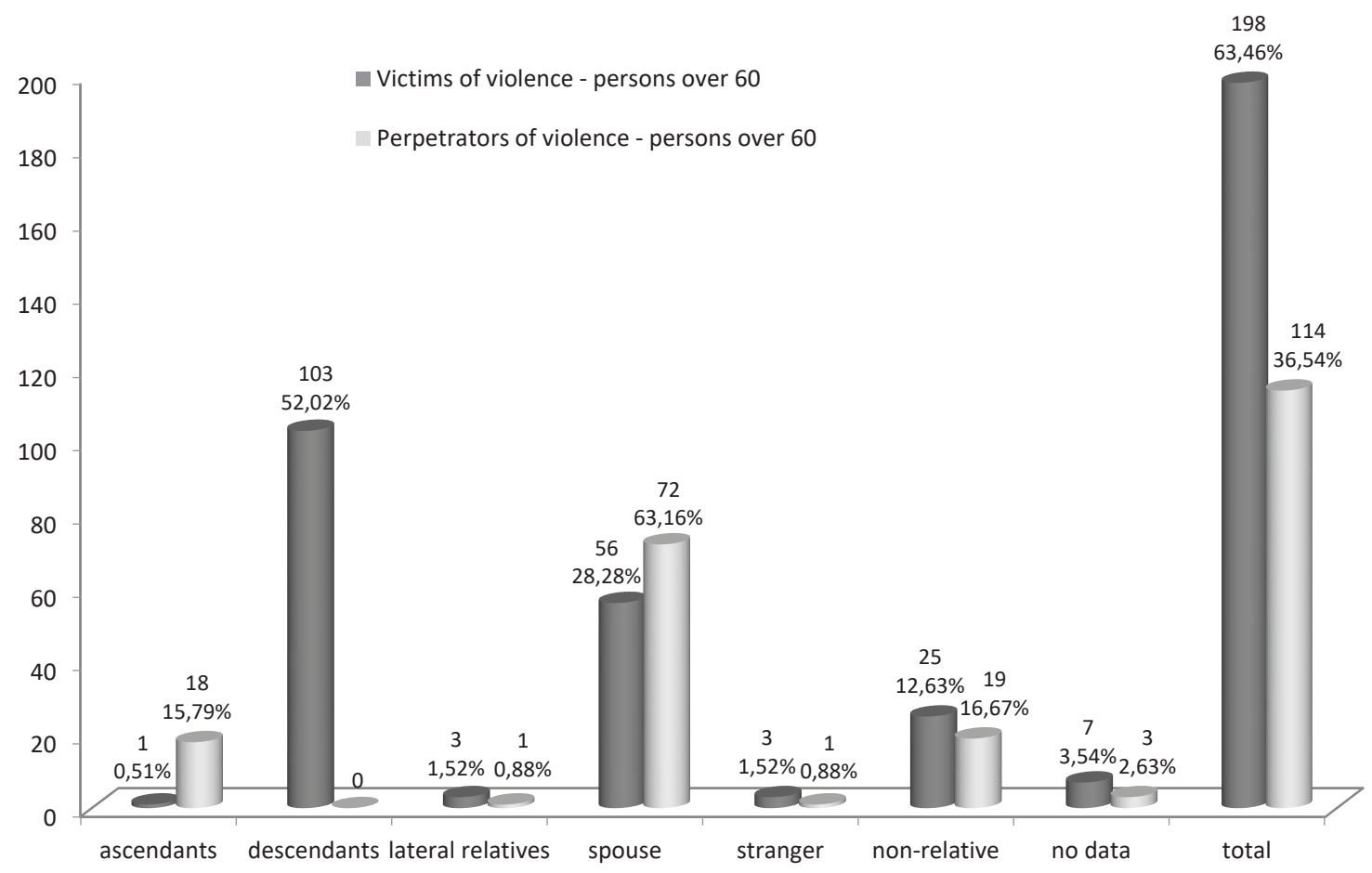

Figure 1. Relationship of individuals involved in violence

or disability, an elderly person is dependent on the assistance and care of family members, and secondly, when the family members are dependent on the elderly person with whom they share accommodation because of the elderly person's possessions, such as an apartment or financial resources. In both cases, these are usually situations of common residence and functioning, and the perpetrators are those closest to the victim [16] (Table 3).

\begin{tabular}{|l|l|l|l|l|}
\hline Table 3. The involvement in violence and its duration \\
\hline Duration of violence & \multicolumn{5}{|l|}{ Victims of violence } & \multicolumn{2}{l|}{$\begin{array}{l}\text { Perpetrators } \\
\text { of violence }\end{array}$} \\
\cline { 2 - 5 } & $n$ & $\%$ & $n$ & $\%$ \\
\hline 1-4 weeks & 4 & 2.02 & 2 & 1.75 \\
\hline 2-12 months & 44 & 22.22 & 11 & 9.65 \\
\hline 1-3 years & 53 & 26.77 & 30 & 26.32 \\
\hline 4-7 years & 27 & 13.64 & 14 & 12.28 \\
\hline Longer & 39 & 19.70 & 39 & 34.21 \\
\hline $\begin{array}{l}\text { Unable to determine } \\
\text { duration }\end{array}$ & 31 & 15.65 & 18 & 15.79 \\
\hline
\end{tabular}

Source: Authors' own research.

In view of the fact that among individuals over 60 years of age violence usually involves spouses and taking into account the duration of violence, it appears that this phenomenon con- tinues for many years before it is disclosed. The forms analyzed in the study apply to individuals born before 1956, i.e. the generation in which the position and role of women were conditioned by a number of factors, both cultural and social, whereas acts of violence were kept secret, as they were considered to be embarrassing and shameful aspects of married life (Table 4).

Another analyzed factor was the behavior of both perpetrators and victims of violence. Despite the large number of "Blue Cards" forms in which questions on behavior were not filled in by the individual initiating the procedure, it has been observed that the majority of the victims were intimidated, quiet or weepy, but not avoiding conversation. In the case of perpetrators of violence, their behavior mostly demonstrated an aggressive attitude and resistance during the intervention operations.

The study also shows that of the 312 cases of violence towards individuals over 60 years of age, it was reported that:

- 48 (42.1\%) perpetrators were already convicted of a crime involving violence or the threat of using violence,

- $43(37.72 \%)$ perpetrators abused alcohol,

- $26(22.8 \%)$ perpetrators used psychotropic substances,

- $40(35.08 \%)$ perpetrators had undergone psychiatric treatment,

- $1(0.87 \%)$ perpetrator was in possession of weapons.

An important element of the study was to analyze the scene of the crime, in 52 cases of which there were visible signs of struggle in the form of broken glass and mirrors, traces of blood,

\begin{tabular}{|c|c|c|c|c|c|c|c|c|c|c|c|c|}
\hline \multirow[t]{3}{*}{ Behavior } & \multicolumn{6}{|c|}{ Victims of violence over 60 years of age } & \multicolumn{6}{|c|}{ Perpetrators of violence over 60 years of age } \\
\hline & \multicolumn{2}{|c|}{\begin{tabular}{|l} 
Yes \\
\end{tabular}} & \multicolumn{2}{|c|}{\begin{tabular}{|l|} 
No \\
\end{tabular}} & \multicolumn{2}{|c|}{ No data } & \multicolumn{2}{|c|}{\begin{tabular}{|l|} 
Yes \\
\end{tabular}} & \multicolumn{2}{|c|}{ No } & \multicolumn{2}{|c|}{ No data } \\
\hline & $n$ & $\%$ & $n$ & $\%$ & $n$ & $\%$ & $n$ & $\%$ & $n$ & $\%$ & $n$ & $\%$ \\
\hline Has difficulty in making contact & 29 & 14.65 & 152 & 76.77 & 17 & 8.58 & 35 & 30.7 & 42 & 36.84 & 37 & 32.46 \\
\hline Quiet & 96 & 48.48 & 84 & 42.42 & 18 & 9.09 & 20 & 17.54 & 55 & 48.24 & 39 & 34.21 \\
\hline Tearful & 84 & 42.42 & 94 & 47.47 & 20 & 10.1 & 4 & 3.5 & 71 & 62.28 & 39 & 34.21 \\
\hline Intimidated & 123 & 62.12 & 61 & 30.8 & 14 & 7.07 & 1 & 0.87 & 74 & 64.91 & 39 & 34.21 \\
\hline Avoids conversation & 12 & 6.06 & 166 & 83.84 & 20 & 10.01 & 18 & 15.78 & 56 & 49.12 & 40 & 35.08 \\
\hline Aggressive & 5 & 2.52 & 171 & 86.36 & 22 & 11.11 & 48 & 42.1 & 26 & 22.8 & 40 & 35.08 \\
\hline Resistant & 0 & 0 & 170 & 85.86 & 28 & 14.14 & 19 & 16.67 & 55 & 48.25 & 40 & 35.08 \\
\hline
\end{tabular}

Source: Authors' own research. 
scattered objects and broken furniture. In 50 cases, the interveners reported the presence of witnesses, most of whom were individuals of different ages living at the same address.

\section{Discussion}

The analysis of the research material points to the fact that in $60.52 \%$ of "Blue Cards" forms, the perpetrators were under the influence of alcohol or psychotropic substances, which confirms that these substances are a decisive factor in the risk of incidents of violence. There are two major hypotheses regarding the relationship between alcohol and violence. The first hypothesis says that alcohol can impair the mechanisms of self-control of aggression, and the second one states that alcohol impairs cognitive processes, which results in an erroneous assessment of the situation. Psychoactive substances, especially alcohol, also limit the ability to find solutions without the use of violence and impair the ability to assess the consequences of actions taken [17]. Substance dependence as a significant risk factor of violent behavior was indicated by Lachs and Pillemer in 1995. It is estimated that approx. $15 \%$ of alcohol abusers are elderly people, $10-15 \%$ of whom are men and $2-5 \%$ are women [8]. Research on the prevalence of elder abuse in the perception of social and medical workers taking care of them shows that individuals whose family members abuse alcohol are most often exposed to violence, which was pointed out by $60 \%$ of the workers from these services $[8,11,17]$. Analysis of the data shows that in 78 cases, representing $25 \%$ of the total, violence was revealed after more than 7 years.

The results of the studies confirm the national statistics. The existing myths still play an important role in imposing silence on older victims of domestic violence, as they state that the victim is the one who is guilty, that older people like to complain, that parents are treated by their children in the same way as they raised them, that you have to carry your cross, and that a woman must know her position [14]. Breaking the silence must be combined with the continuing education of the public in this respect [15]. Studies conducted on violence against older people also rely on direct contact, mainly with the victims. Such studies conducted by Halicka demonstrated that the examined women drew attention to the need to seek help and support "outside" and recommended prudence and an active attitude towards the perpetrator [19]. This attitude of the seniors was confirmed by research conducted among students of the Third Age University in Wroclaw by Wróblewska, Steciwko and Błaszczuk. The research found that individuals experiencing violence and who decided to seek help reported it to the police, doctors, neighbors, family members or other relevant institutions [20]. A relationship between psychiatric treatment and violence should also be emphasized. This connection is confirmed by approx. $57 \%$ of social and medical workers [8]. The results of the research by Holtzworth-Munroe and Stuart, presenting typologies of perpetrators of violence in relation to mental disorders, mostly indicate those that have a significant effect on the perception of reality by an individual, i.e. schizophrenia, affective disorders, drug abuse syndromes and psychoses associated with alcohol withdrawal. However, the authors point out that aggression is most often the result of discontinuation of therapy [21].

Initiation of the "Blue Cards" procedure provides information for the police, health, education and social services that there is violence in the family and that action must be taken. An important element of the procedure is to monitor the environment by the services, which may be unannounced, on different days and at different hours in order to control the behavior of perpetrators of violence. In health/life-threatening situations, the individual experiencing violence is guaranteed safe accommodation. Unfortunately, in the case of the elderly, the most common form of accommodation is a social assistance home. The "Blue Cards" procedure is still one of the few examples of regulations that make it possible to take preventive action and intervention without the need for the court to determine whether there has been a violation of the law [22]. An unquestionable advantage of the tested material is its interdisciplinarity and insight in a large amount of detailed information concerning the individuals involved in violence. A limitation of the research process was the frequent lack of data resulting from the activities of the services initiating the procedure. This, however, did not significantly affect the overall assessment of the phenomenon. The analysis of the "Blue Cards" questionnaires leads to the following reflection: on the one hand, the elderly are a group vulnerable to abuse and neglect by their loved ones, but on the other hand, older people also inflict harm and suffering on members of their families. It is therefore appropriate to undertake studies, analyses and evaluations which will allow to make a diagnosis of violence among the elderly, but at the same time, it is necessary to take measures that will effectively and permanently prevent incidences of this phenomenon.

\section{Conclusions}

1. It is difficult to establish the number of cases of domestic violence among individuals over 60 years of age. The obtained data does not reflect the true extent of the phenomenon, as many older people experiencing violence do not disclose their problem, mainly due to shame or fear.

2. The perpetrators of violence against the elderly are individuals abusing alcohol and other psychoactive substances. These are factors triggering violent behavior.

3. Violence among the elderly is not incidental; it lasts from one to more than ten years.

4. The individuals most vulnerable to acts of violence are women, who experience it from their spouses.

5. During police intervention, perpetrators of violence are aggressive and resistant, while victims of violence are intimidated, quiet and tearful, but not avoiding conversation.

Source of funding: Paper developed using the university's funds statute-based activity, WNoZ 303-01/S/12/16. Conflict of interest: The authors declare no conflict of interests.

\section{References}

1. World report on violence and health. Geneva: World Health Organization; 2002: 19.

2. Halicka M. Elder abuse and neglect in Poland. J Elder Abuse Negl 1995; 3-4: 157-169.

3. WHO: miliony starszych osób są ofiarami przemocy fizycznej [cited 28.03.2016]. Available from URL: http://www.rynekzdrowia.pl/ Uslugi-medyczne/WHO-miliony-starszych-osob-sa-ofiarami-przemocy-fizycznej,109962,8.html.

4. Raport Polki 50 plus. Zdrowie i jego zagrożenia. Fundacja MSD dla Zdrowia Kobiet; Narodowy Instytut Zdrowia Publicznego - Państwowy Zakład Higieny [cited 28.03.2016]. Available from URL: http://www.rynekzdrowia.pl/Plik/145777.html.

5. Simone L, Wettstein A, Senn O, et al. Types of abuse and risk factors associated with elder abuse. Swiss Med Wkly 2015; 146: w14273, doi: 10.4414/smw.2016.14273.

6. Sygit E, Ossowski R. Przemoc wobec osób starszych ze względu na ich wiek, płeć i wykształcenie. Gerontol Pol 2008; 16(3): 163-168. 
7. Woźniak B, Tobiasz-Adamczyk B, Brzyska M. Omówienie wyników projektu Breaking the Taboo. Empowering health and social service professionals to combat violence against older women within families. Polska na tle wybranych krajów europejskich. Część 1. Gerontol Pol 2010; 18(1): 33-40.

8. Tobiasz-Adamczyk B. Przemoc wobec osób starszych. Kraków: Wydawnictwo Uniwersytetu Jagiellońskiego; 2009: 16, 43.

9. Wyniki badań WYG PSDB dla Ministerstwa Pracy i Polityki Społecznej. Projekt "Rodzina Polska wolna od przemocy" dla Programu Operacyjnego PL14: „Przeciwdziałanie przemocy w rodzinie i przemocy ze względu na płeć". Warszawa: WYG PSDB; 2014: $107-111$.

10. Stanek K. Praca socjalna z osobq lub rodzinq z problemem przemocy. Warszawa: Centrum Rozwoju Zasobów Ludzkich; $2014: 21$.

11. The „Blue Cards” procedure in police statistics [cited 27.02.2016]. Available from URL: http://statystyka.policja.pl/.

12. Ustawa z dnia 29 lipca 2005 roku o przeciwdziałaniu przemocy w rodzinie (Dz.U. z 2005 r., nr 180, poz. 1493 ze zm.)

13. Government Order of 13 September 2011 on the "Blue Cards" procedure and the model of the "Blue Cards" forms (OJ 2011 No 209 , item 1245).

14. Główny Urząd Statystyczny. Ludność. Stan i struktura ludności w przekroju terytorialnym. Stan w dniu 31 XII 2014. Warszawa: Główny Urząd Statystyczny; 2015.

15. Kaczan R, Podgórna K. Zapobieganie przemocy wobec osób starszych na przykładzie kampanii społecznych w Kanadzie. Instytucjonalne wsparcie seniorów - rozwiqzania polskie i zagraniczne. Bielsko-Biała: Wyższa Szkoła Administracji; 2007: 85-98.

16. Canada. The National Clearinghouse on Family Violence. (2000). Abuse and Neglect of Older Adults: A Discussion Paper. Ottawa: „Family Violence Prevention Unit" [cited: 25.06.2015]. Available from URL: http://healthcanada.ca/.

17. Fudała J, Dąbrowska K, Łukowska K. Uzależnienie od alkoholu - między diagnozq a działaniem: 103-110. Available from URL: http:// irss.pl/wp-content/uploads/2013/11/Uzale\%C5\%BCnienie\%20od\%20alkoholu\%20-\%20\%20mi\%C4\%99dzy\%20diagnoz\%C4\%85\%20 a\%20dzia\%C5\%82aniem.pdf.

18. Durda R. Przeciwdziałanie przemocy wobec osób starszych. Doświadczenia Ogólnopolskiego Pogotowia dla Ofiar Przemocy w Rodzinie „Niebieska Linia” IPZ. 2016 [cited 15.03.2016]. Available from URL: http://docplayer.pl/6059080-Przeciwdzialanie-przemocy-wobecosob-starszych-doswiadczenia-ogolnopolskiego-pogotowia-dla-ofiar-przemocy-w-rodzinie-niebieska-linia-ipz.html.

19. Halicka M. Przemoc wobec starszych kobiet - wywiady z ofiarami. Praca Socjalna 2012; 5: 132-175.

20. Wróblewska I, Steciwko A, Błaszczuk J. Zjawisko przemocy w rodzinie występujące wśród słuchaczy Uniwersytetu Trzeciego Wieku we Wrocławiu. Fam Med Prim Care Rev 2012; 14(3): 444-446.

21. Holtzworth-Munroe A, Stuart GL. Typologies of male batterers: three subtypes and the differences among them. Psychol Bull 1994; 116(3): 476-497.

22. Kuczyńska S, Wrona G. Lekarzu reaguj na przemoc! Przewodnik dla pracowników ochrony zdrowia. Warszawa-Kraków: Instytut Łukasiewicza, Państwowa Agencja Rozwiązywania Problemów Alkoholowych; 2013: 21.

Tables: 4

Figures: 1

References: 22

Received: 27.06 .2016

Revised: 19.09 .2016

Accepted: 05.10.2016

Address for correspondence:

Marta Giezek, PhD

Miejski Ośrodek Pomocy Rodzinie

ul. Sikorskiego 3

70-323 Szczecin

Polska

Tel.: +48 669 290-372

E-mail: martagiezek@wp.pl 